\title{
Characterization of genes differentially expressed within macrophages by virulent and attenuated Mycobacterium tuberculosis identifies candidate genes involved in intracellular growth
}

Correspondence

Richard W. Stokes

rstokes@interchange.ubc.ca

Received 4 January 2008

Revised 16 April 2008

Accepted 16 April 2008
Alice H. Li, ${ }^{1}$ Wan L. Lam ${ }^{2}$ and Richard W. Stokes ${ }^{3}$

\author{
${ }^{1}$ Department of Pathology and Laboratory Medicine, University of British Columbia, 950 West 28th \\ Avenue, Vancouver, BC V5Z 4H4, Canada \\ ${ }^{2}$ Department of Pathology and Laboratory Medicine, University of British Columbia, Department of \\ Cancer Genetics, BC Cancer Research Centre, 601 West 10th Avenue, Vancouver, BC V5Z 1L3, \\ Canada \\ ${ }^{3}$ Departments of Paediatrics and Pathology and Laboratory Medicine, University of British \\ Columbia, Division of Infectious and Immunological Diseases, BC Children's Hospital, 950 West \\ 28th Avenue, Vancouver, BC V5Z 4H4, Canada
}

To identify genes involved in the intracellular survival of Mycobacterium tuberculosis we compared the transcriptomes of virulent (H37Rv) and attenuated $(\mathrm{H} 37 \mathrm{Ra})$ strains during their interaction with murine bone-marrow-derived macrophages. Expression profiling was accomplished via the bacterial artificial chromosome fingerprint array (BACFA) technique. Genes identified with BACFA, and confirmed via qPCR to be upregulated in the attenuated H37Ra at $168 \mathrm{~h}$ postinfection, were $f r d B, f r d C$ and $f r d D$. Genes upregulated in the virulent $\mathrm{H} 37 \mathrm{Rv}$ were pks2, aceE and $R v 1571$. Further qPCR analysis of these genes at 4 and $96 \mathrm{~h}$ post-infection revealed that the frd operon (encoding the fumarate reductase enzyme complex) is expressed at higher levels in the virulent H37Rv at earlier time points while the expression of ace $E$ and pks2 is higher in the virulent strain throughout the course of infection. Assessment of frd transcripts in oxygen-limited cultures of M. tuberculosis H37Ra and H37Rv showed that the attenuated strain displayed a lag in $\operatorname{frd} A$ and $\operatorname{frd} B$ expression at the onset of microaerophilic culture, when compared to microaerophilic cultures of H37Rv and aerated cultures of H37Ra. Lastly, treatment of intracellular bacteria with a putative inhibitor of fumarate reductase resulted in a significant reduction of bacterial growth.

\section{INTRODUCTION}

Tuberculosis (TB) affects one-third of the global population, and kills an estimated two to three million people every year (Dolin et al., 1994). Current vaccines and chemotherapeutic measures are limited in their efficacy and are failing to prevent the incidence of TB. In the last two decades, the emergence of multi-drug resistant strains of the causative agent, Mycobacterium tuberculosis, and the increased susceptibility of AIDS patients to both infection and reactivation of disease have been observed (Narain et al., 1992; Selwyn et al., 1989). Furthermore, with an increasingly mobile population, it has become easier for tuberculosis to spread to areas with lax preventative

Abbreviations: BACFA, bacterial artificial chromosome fingerprint array; $\mathrm{BM}-\mathrm{M} \Phi$, bone-marrow-derived macrophages; FRD, fumarate reductase; MNPO, mercaptopyridine- $N$-oxide; qPCR, quantitative real-time PCR; $\mathrm{SDH}$, succinate dehydrogenase; TB, tuberculosis. measures against the disease. M. tuberculosis is an intracellular pathogen that is able to successfully evade host defences, enabling its survival within the host. However, even with the insight gained recently into mycobacterial gene expression via novel techniques such as SCOTS (Graham \& Clark-Curtiss, 1999), subtractive hybridization (Kinger \& Tyagi, 1993; Li et al., 2001) and differential display (Mostowy et al., 2004; Rindi et al., 1999; Rivera-Marrero et al., 1998), and especially the profusion of information uncovered by microarray technology (Bacon et al., 2004; Mostowy et al., 2004; Schnappinger et al., 2003; Waddell et al., 2005; Wei et al., 2000), much remains to be understood about the molecular aspects of mycobacterial pathogenesis in relation to the host cell.

The bacterial model applied in this study is that of $M$. tuberculosis $\mathrm{H} 37 \mathrm{Ra}$ and $\mathrm{H} 37 \mathrm{Rv}$, sibling strains derived from the parental H37 (Oatway \& Steenken, 1936; Steenken et al., 1934), a laboratory strain originally isolated from the 
sputum of a pulmonary TB patient in 1906 (Steenken \& Gardner, 1946). Strains H37Ra and H37Rv are highly similar, as studies have shown little genomic difference between them (Bhargava et al., 1990; Collins \& De Lisle, 1984; Imaeda, 1985), save for the RvD2 region of difference (Brosch et al., 1999; Lari et al., 2001), which has not been conclusively linked to pathogenesis (Lari et al., 2001). However, in spite of this lack of genomic differences between the strains, $\mathrm{H} 37 \mathrm{Rv}$ has been shown to display a marked advantage in survival and growth in animal hosts over that of H37Ra (Collins \& Smith, 1969; Jung et al., 2002). Thus, dissecting the molecular aspects of the phenotypic differences between these highly related strains may lead to a better understanding of mycobacterial virulence.

Studies comparing the expression differences between broth-grown H37Ra and H37Rv and/or intracellular and broth-grown $\mathrm{H} 37 \mathrm{Ra} / \mathrm{Rv}$ bacteria have elucidated genes differentially expressed between the strains, some of which have been shown to have roles in mycobacterial virulence (Graham \& Clark-Curtiss, 1999; Kinger \& Tyagi, 1993; Rindi et al., 1999, 2001; Rivera-Marrero et al., 1998; Wei et al., 2000; Gao et al., 2004). For example, Gao et al. (2004) examined, via microarray, genes involved in the cording and non-cording phenotypes of the respective H37Rv and H37Ra. Graham \& Clark-Curtiss (1999) developed the novel SCOTS technique to minimize the noise introduced by rRNA populations and, in their comparisons of the transcriptomes of broth-grown and intracellular $M$. tuberculosis $\mathrm{H} 37 \mathrm{Rv}$, they were able to isolate several genes upregulated in intracellular $M$. tuberculosis. One of these genes was $p k s 2$, a putative polyketide synthase which has been found to play a role in the synthesis of sulpholipid (Sirakova et al., 2001), an important component of the mycobacterial cell wall. Furthermore, Kinger \& Tyagi (1993) examined, via differential display, genes differentially expressed between aerobic cultures of $M$. tuberculosis H37Ra and H37Rv.

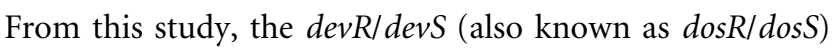
two-component system was identified, which has subsequently been found to have a role in the survival of $M$. tuberculosis under anoxic conditions (Dasgupta et al., 2000; Guinn et al., 2004; Park et al., 2003; Saini et al., 2004; Wei et al., 2000). These studies highlight the value of the H37Rv/H37Ra model in the search for genes that may have a role in $M$. tuberculosis pathogenesis.

Our study also utilized the H37Rv/H37Ra model; however, we reasoned that gene expression changes that would affect bacterial survival and growth within host cells are more likely to be discovered by focusing on differences between $\mathrm{H} 37 \mathrm{Ra}$ and $\mathrm{H} 37 \mathrm{Rv}$ expression when both strains are in interaction with macrophages rather than by comparing broth-grown with intracellular bacteria. To assess these transcriptome changes between strains, we used a novel technique - bacterial artificial chromosome fingerprint array (BACFA) - that has been successfully utilized for comparative genomic studies (Brosch et al., 1998, 1999;
Gordon et al., 1999a). We also provide evidence that, through use of BACFA, we have identified an enzyme complex, fumarate reductase, that aids the survival of intracellular M. tuberculosis.

\section{METHODS}

Bacterial strains. For growth curve assessments and macrophage infections, M. tuberculosis $\mathrm{H} 37 \mathrm{Rv}$ and H37Ra were grown as aerated cultures in roller bottles ( 3 r.p.m.) until late-exponential phase in Proskauer and Beck medium supplemented with $0.05 \%$ Tween 80 $(\mathrm{PB}+\mathrm{T})$. Samples $(2 \mathrm{ml})$ were taken from cultures each day to assess turbidity and viable count. Doubling times were calculated from viable counts collected on days 0 and 5 - this being representative of the exponential phase of bacterial growth for both H37Ra and H37Rv. For fumarate reductase studies using cultures grown under oxygenlimiting conditions (Wayne, 1976), $10 \mathrm{ml}$ volumes of $\mathrm{PB}+\mathrm{T}$ cultures inoculated with the respective strains were seeded into $14 \mathrm{ml}$ polystyrene tubes. The tubes were tightly capped and left undisturbed at $37^{\circ} \mathrm{C}$. At designated time points, the tubes were inverted to resuspend the sedimented bacterial pellet and immediately processed for RNA. For broth culture transcriptome studies, bacteria were grown as aerated cultures in roller bottles in either $\mathrm{PB}+\mathrm{T}$ or $7 \mathrm{H} 9$ supplemented with $0.05 \%$ Tween 80 and $10 \%$ OADC (oleic acid/ albumin/dextrose-complex). Doubling times were calculated from viable counts collected on days 0 and 5 using the following equation: doubling time $(\mathrm{h})=\left(t \times \log _{10} 2\right) \div\left(\log _{10} N_{t}-\log _{10} N_{0}\right)$, where $t=$ time elapsed in hours, $N_{t}=$ number of bacteria at time $t$ and $N_{0}=$ number of bacteria at time 0 (Madigan et al., 1997b; Monod, 1949).

Isolation and culturing of bone-marrow-derived macrophages (BM-MФ). BM-MФ were obtained from the femora, tibiae and humeri of CD-1 mice as previously described (Rooyakkers \& Stokes, 2005; Stokes et al., 1993). Briefly, the bones were dissected out from euthanized, 7-10-week-old female CD-1 mice, and the marrow was flushed from the bones using BM-MФ medium [RPMI containing $10 \%$ heat-inactivated fetal calf serum, $10 \%$ L-929 cell medium (Rooyakkers \& Stokes, 2005), $2 \mathrm{mM} \mathrm{L-glutamine} \mathrm{and}$ $1 \mathrm{mM}$ sodium pyruvate]. The cell suspension was left to adhere in a $175 \mathrm{~cm}^{2}$ flask for $3 \mathrm{~h}$ to deplete non-stem cells. Non-adherent cells (stem cells) were collected and cultured for 7 days in BM-MФ medium at $37{ }^{\circ} \mathrm{C}$ with $5 \% \mathrm{CO}_{2}$ to allow differentiation into macrophages in $150 \mathrm{~cm}^{2}$ tissue culture flasks for RNA studies, or on $13 \mathrm{~mm}$ diameter coverslips for c.f.u. determinations (Rooyakkers \& Stokes, 2005).

Infection and determination of macrophage-associated growth of $\boldsymbol{M}$. tuberculosis. To assess bacterial expression profiles $96 \mathrm{~h}$ and $168 \mathrm{~h}$ post-infection, monolayers were incubated at an m.o.i. of 10 bacteria to 1 macrophage, which resulted in an average infection rate (average c.f.u. at $4 \mathrm{~h}$ per macrophage plated in the well) of 0.1 bacteria per macrophage. After a $4 \mathrm{~h}$ incubation with binding

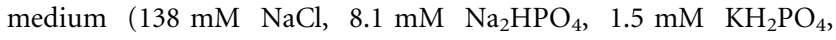
$2.7 \mathrm{mM} \mathrm{KCl}, 0.6 \mathrm{mM} \mathrm{CaCl}_{2}, 1.0 \mathrm{mM} \mathrm{MgCl}_{2}$ and $5.5 \mathrm{mM}$ D-glucose) containing the requisite number of bacteria, the monolayers were washed three times with pre-warmed medium to rinse off unbound bacteria, before being submerged in cRPMI (RPMI 1640 with $10 \%$ fetal calf serum, $2 \mathrm{mM}$ L-glutamate and $1 \mathrm{mM}$ sodium pyruvate) until they were to be processed for RNA at days 4 and 7 postinfection. To assess bacterial expression at $4 \mathrm{~h}$ post-infection, monolayers were infected at an m.o.i. of 60 bacteria to 1 macrophage, resulting in an average infection rate of 0.6 bacteria per macrophage. This higher m.o.i. was used to allow for the harvest of a sufficient amount of bacterial RNA and was comparable to the bacterial load in macrophages 4 days post-infection at an m.o.i. of 10:1 (data not 
shown). At each time point, coverslips and supernatants were briefly sonicated (10 s) to release and disperse bacteria, and plated on 7H10 agar plates supplemented with $10 \%$ OADC to determine c.f.u. per $\mathrm{ml}$ (Rooyakkers \& Stokes, 2005). For all macrophage experiments, three replicate coverslips were assessed at each time point for each of three independent experiments.

Extraction and purification of bacterial RNA. RNA was extracted from broth cultures as previously described (Mangan et al., 1997; Stewart et al., 2002). For intracellular bacteria used to examine $M$. tuberculosis expression profiles at 96 and $168 \mathrm{~h}$ post-infection, $50 \mathrm{ml}$ GTC lysis buffer (Monahan et al., 2001) was added to each flask at the designated time and rocked gently until Schlieren lines disappeared, indicating homogeneous mixing of the solutions. For intracellular bacteria used to examine mycobacterial expression at $4 \mathrm{~h}$ post-infection, flasks were washed three times with prewarmed medium, and $50 \mathrm{ml}$ GTC lysis buffer was poured directly onto the monolayer. The entire contents of flasks were poured into $50 \mathrm{ml}$ conical tubes, and spun at 3700 r.p.m. (3500 g) for $15 \mathrm{~min}$. Pellets were resuspended and pooled with $1 \mathrm{ml}$ GTC lysis buffer. RNA was extracted from the pellets and then purified as previously described (Mangan et al., 1997; Stewart et al., 2002; Wernisch et al., 2003).

Reverse transcription and cDNA synthesis. For BAC arrays, 1$5 \mu \mathrm{g}$ total RNA was reverse transcribed with Superscript II (Invitrogen) and a universal arbitrary primer (5'-GCCGGAGCTCTGCAGAATTC-3'), henceforth called Uniprime, was used to generate single-stranded cDNA (Mangan \& Butcher, 1998). Eight units of Klenow fragment of DNA polymerase I (Invitrogen) was then used to synthesize second-strand cDNA according to previously published protocols (Mangan \& Butcher, 1998).

DIG-labelling of cDNA for use in BACFA. A $2 \mu$ aliquot of doublestranded cDNA was added to $8 \mu \mathrm{l}$ water, boiled for $10 \mathrm{~min}$ and added to the following: $2 \mu \mathrm{l} 10 \times$ PCR buffer (Invitrogen), $2.5 \mu \mathrm{l} 2 \mathrm{mM}$ DIG-dUTP : dTTP (3:1 ratio), $2.5 \mu 12 \mathrm{mM}$ dNTPs (dATP, dCTP, dGTP), $0.8 \mu \mathrm{l} 50 \mu \mathrm{M}$ Uniprime stock solution, $0.6 \mu \mathrm{l} 50 \mathrm{mM} \mathrm{\textrm {MCl } _ { 2 }}$ and $1 \mathrm{U}$ Taq Polymerase (Invitrogen), to a final volume of $20 \mu \mathrm{l}$. DIG labelling of cDNA was then done via PCR $\left(94{ }^{\circ} \mathrm{C}\right.$ for $2 \mathrm{~min}$ followed by 30 cycles of $94{ }^{\circ} \mathrm{C}, 55{ }^{\circ} \mathrm{C}$ and $72{ }^{\circ} \mathrm{C}$ for 1,2 and $3 \mathrm{~min}$, respectively).

Generation of bacterial artificial chromosome fingerprint arrays (BACFAs). The M. tuberculosis H37Rv BAC library was kindly provided by Drs Stewart Cole and Roland Brosch at the Pasteur Insitute (Paris, France), who used it to isolate and identify genomic differences between H37Ra and H37Rv (Brosch et al., 1998, 1999; Gordon et al., 1999b). This library contains 78 BACs, each containing an average of $68 \mathrm{~kb}$ of genomic sequence from H37Rv. For preliminary BACFA assessment of differential expression between H37Ra and H37Rv, all BACs were digested with $10 \mathrm{U}$ each of $P v u \mathrm{II}$ and StuI (New England Biolabs) overnight at $37{ }^{\circ} \mathrm{C}$. After preliminary screening, some BACs were digested with StuI and Sall. The BACs of interest were first digested with Sall overnight at $37^{\circ} \mathrm{C}$; the products were cleaned with a Qiagen PCR purification column and eluted with $20 \mu \mathrm{l}$ water. Eluted volumes were then digested overnight at $37^{\circ} \mathrm{C}$ with $10 \mathrm{U}$ StuI.

Digestion products were run on a $1.5 \%$ TAE-agarose gel for $2 \mathrm{~h}$ at $80 \mathrm{~V}$. Southern transfer of fragments to nylon membrane was done by the manufacturer's protocol (Roche). Fragments were immobilized onto nylon membranes by UV cross-linking at $260 \mathrm{~nm}$ for $5 \mathrm{~min}$ followed by baking at $80{ }^{\circ} \mathrm{C}$ for $2 \mathrm{~h}$.

Generation of BACFA hybridization profiles. Nylon membranes were hybridized according to the manufacturer's instructions with
$2.5 \mu \mathrm{l}$ DIG-labelled PCR reaction product (above) per ml hybridization buffer. Membranes were hybridized for $16-18 \mathrm{~h}$ at $50{ }^{\circ} \mathrm{C}$. Immunological detection of blots was carried out by the manufacturer's protocols (Roche). Profiles were generated in duplicate for each of three independent pools of cDNA from H37Ra and H37Rv. Differences were only singled out if they appeared in all six profiles.

Quantitative real-time PCR (qPCR) analysis of expression differences observed with BACFA. As hybridization protocols could potentially allow for non-specific binding resulting in a false positive, all differences identified via BACFA were assessed via $\mathrm{qPCR}$. Using gene-specific primers, this technique allows for unambiguous expression analysis of the candidates. Second-strand cDNA generated with the universal primer was used in qPCRs with SYBR Green as the indicator dye. For qPCRs, primers were designed with PrimerQuest, a web-based program freely available from the IDT website (http:// www.idtdna.com/Scitools/Applications/Primerquest/), as well as Primer Software from Molecular Biology Tools. Primers were designed with an annealing temperature of $57{ }^{\circ} \mathrm{C}$, and used at a final concentration of $300 \mathrm{nM}$ in a reaction volume of $20 \mu \mathrm{l}$. qPCR cycling conditions were as follows: $95{ }^{\circ} \mathrm{C}$ for $10 \mathrm{~min}$ followed by 35 cycles of $94{ }^{\circ} \mathrm{C}$ for $30 \mathrm{~s}, 57{ }^{\circ} \mathrm{C}$ for $20 \mathrm{~s}$, and $72{ }^{\circ} \mathrm{C}$ for $30 \mathrm{~s}$. qPCR data are presented as fold difference of expression in H37Ra over that in $\mathrm{H} 37 \mathrm{Rv}$ using the $2^{-\Delta \Delta \mathrm{Ct}}$ method (Schmittgen et al., 2000), with rrnAP1(Menendez Mdel et al., 2005) and dnaK used as normalizing genes for the $96 \mathrm{~h}$ and $168 \mathrm{~h}$ transcripts, and $\operatorname{rrnAP} 1$ and $16 S$ used as normalizing genes for $4 \mathrm{~h}$ transcripts. $16 S$ was used in addition to rrnAP1 at 4 h post-infection as it was found to be more reliable at the earlier time point compared to the later time point. Two normalizing genes were used for each time point as previous reports have shown that normalizing genes do not necessarily stay constant over time and that more than one is needed for reliable expression analysis (Vandesompele et al., 2002).

Treatment of extracellular and intracellular bacteria with mercaptopyridine-N-oxide (MPNO). We assessed bacterial viability in the presence of MPNO, a putative inhibitor of fumarate reductase. Frozen aliquots of $M$. tuberculosis $\mathrm{H} 37 \mathrm{Ra}$ and $\mathrm{H} 37 \mathrm{Rv}$ were thawed, and diluted to $6 \times 10^{6} \mathrm{ml}^{-1}$ in $7 \mathrm{H} 9$. Aliquots $(200 \mu \mathrm{l})$ of the bacterial suspension were then dispensed into 96-well plates and incubated at $37{ }^{\circ} \mathrm{C}$ for $72 \mathrm{~h}$ to produce actively growing bacteria. At $72 \mathrm{~h}$, stock MPNO (10 mM in water) was added to wells to give a final concentration ranging from 0 to $4.8 \mu \mathrm{M}$ and incubated for a further $72 \mathrm{~h}$. Then $50 \mu \mathrm{l}$ Alamar Blue reagent was added to each well; the plate was left at $37{ }^{\circ} \mathrm{C}$ for $24 \mathrm{~h}$ and read at both $550 \mathrm{~nm}$ and $570 \mathrm{~nm}$ on a Bio-Rad microplate reader. Analysis of Alamar Blue reduction as a measure of bacterial viability was done according to the manufacturer's protocol (TREK Diagnostic Systems, Fisher Biosciences).

To monitor the effects of MPNO on intracellular mycobacteria, monolayers of BM-M $\Phi$ were infected as described above. After infection, the monolayers were washed thoroughly to remove unbound bacteria and three replicate coverslips were removed to assess the numbers of bacteria bound/internalized by macrophages. Half of the remaining coverslips were overlaid with cRPMI supplemented with $2.4 \mu \mathrm{M}$ MPNO whilst the other half were overlaid with unsupplemented cRPMI. Coverslips and supernatants were processed at 96 and $168 \mathrm{~h}$ post-infection as described above to monitor intracellular bacterial growth.

Statistics. Statistical significance of comparisons between H37Rv and H37Ra, or between two time points, was determined with the two-tailed, unpaired Student's $t$ test. $P$ values $<0.05$ were considered significant. 


\section{RESULTS}

\section{Growth of M. tuberculosis H37Ra and H37Rv does not differ in enriched broth, but does within macrophages}

In $\mathrm{PB}+\mathrm{T}$ broth, the growth of $M$. tuberculosis H37Ra and H37Rv (Fig. 1a) was not significantly different when their respective doubling times during exponential growth were compared (H37Ra, 23.0 $\pm 1.1 \mathrm{~h} ; \mathrm{H} 37 \mathrm{Rv}, 24.1 \pm 2.4 \mathrm{~h}$, $P=0.6973$; Fig. 1b). However, a significant difference in growth rate was observed between the two strains during intracellular growth in BM-M $\Phi$ (Fig. 1c). Assessing growth of intracellular bacteria at day $7(168 \mathrm{~h})$ following infection of $\mathrm{BM}-\mathrm{M} \Phi$ the doubling time of $\mathrm{H} 37 \mathrm{Rv}$ was $31.2 \pm 1.3 \mathrm{~h}$, whereas the doubling time of $\mathrm{H} 37 \mathrm{Ra}$ was $51.1 \pm 1.4 \mathrm{~h}$
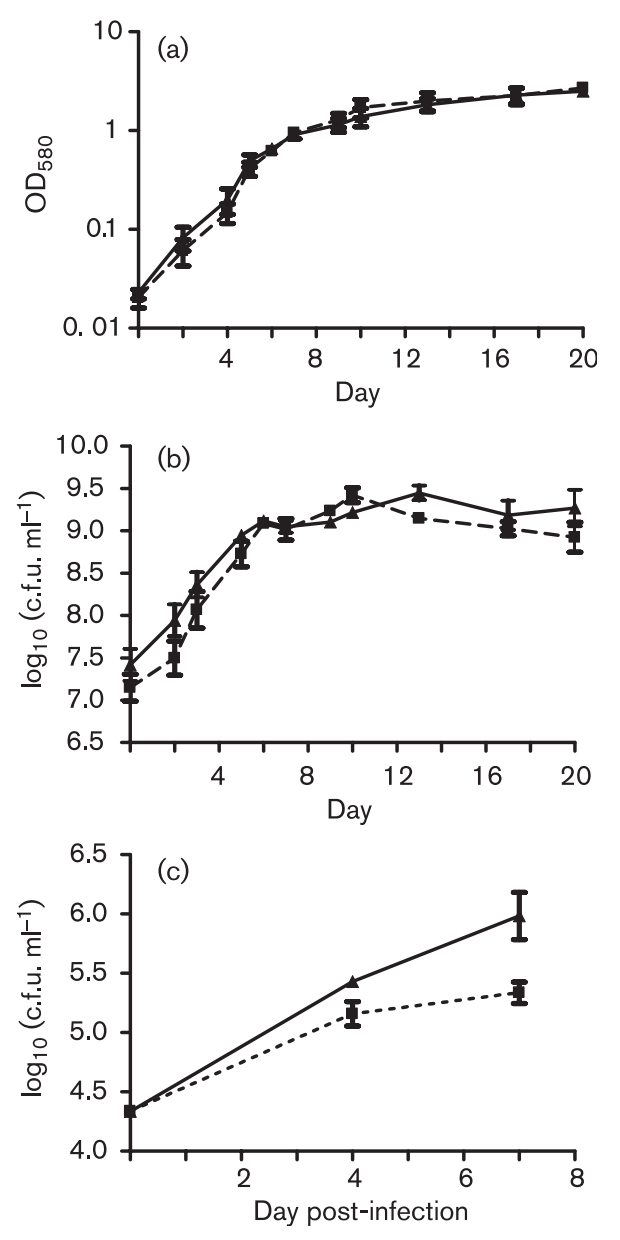

Fig. 1. Growth of $M$. tuberculosis H37Ra ( $\mathbf{a}$, dashed lines) and H37Rv ( $\boldsymbol{\Delta}$, full lines) in $\mathrm{PB}+\mathrm{T}$ monitored via $\mathrm{OD}_{580}(\mathrm{a})$ and via c.f.u. $\mathrm{ml}^{-1}$ (b), and inside murine BM-MФ (c). For broth-grown mycobacteria, cultures were grown under aerated conditions in roller bottles. For assessment of growth inside macrophages, murine $\mathrm{BM}-\mathrm{M} \Phi$ were infected at a ratio of 10 bacteria to 1 macrophage. Data are means \pm SEM of three independent experiments.
$(P=0.014)$. While not significant, a marked difference in growth between strains was observed on day $4(96 \mathrm{~h})$ postinfection (for H37Ra and for H37Rv, $P=0.1058$, Fig. 1c). This difference represents an inhibition of growth of the attenuated strain when inside macrophages, but not when grown in broth culture.

\section{Analysis of BACFA hybridization profiles reveals differences in gene expression between intracellular H37Rv and H37Ra}

To identify differences between strains, BACFAs generated with the enzymes PvuII and StuI were hybridized with

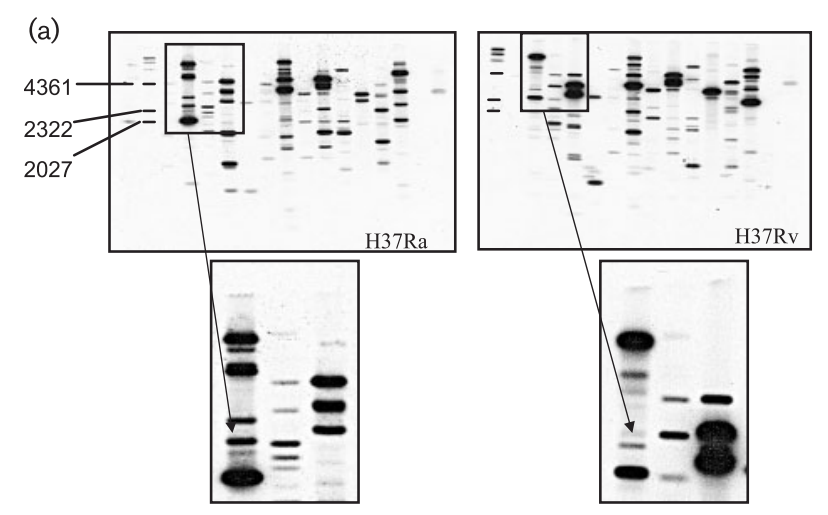

(b)

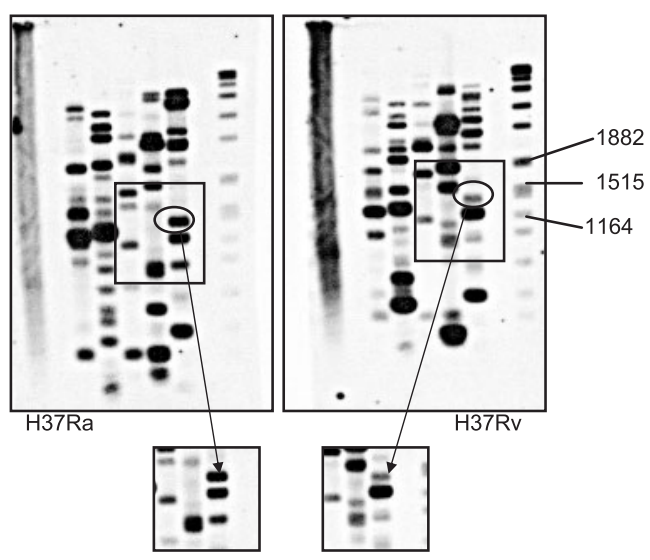

Fig. 2. Bands of interest seen in BACFA comparisons may represent several $\mathrm{kb}$. Preliminary screenings were done with BACFAs generated with Pvull and Stul, but as seen here in (a), the band of interest expressed at a higher level in H37Ra falls into the $2.4 \mathrm{~kb}$ range, containing several genes. Thus, it was necessary to generate a second set of BACFAs (b) with Stul and Sall. The second set of BACFAs were hybridized with the same probes, and new expression profiles were obtained (b). By using the Restriction Site Digest program, the $2.3 \mathrm{~kb}$ band in (a) was predicted to yield a band of approximately $1.5 \mathrm{~kb}$ (circled in b) containing the genes $f r d B, f r d C$ and $f r d D$. DIG-labelled DNA molecular mass markers with corresponding base-pair amounts are indicated in both (a) and (b). 
three different pools of DIG-labelled cDNA probes (Fig. 2). Presence or absence of bands in the hybridization profiles and, in some cases, marked changes in band intensity were designated expression differences. Only differences seen in all three cDNA populations were chosen as candidates for further investigation. To identify genes in the bands of interest, the program Restriction Site Digest was used (http://www.flintbox.com/technology.asp?Page=3352). This program allows the user to digest sequences in silico with restriction enzymes of interest, and provides both a pictorial image of how an ideal digest should run on an agarose gel, as well as a text file of the sizes and sequences of all restriction digest products.

In certain instances, a second set of enzymes, StuI and SalI, was used to generate new BACFAs to further investigate candidate differences in large fragments, which would contain several genes. For example, in one case, a PvuII/ StuI $2.4 \mathrm{~kb}$ fragment displayed a band of higher intensity when hybridized with $\mathrm{H} 37 \mathrm{Ra}$ probes versus $\mathrm{H} 37 \mathrm{Rv}$ probes (Fig. 2a). To narrow down the potential candidate genes to be confirmed via qPCR, Restriction Site Digest was used to predict the enzymes needed to cut this fragment. StuI and Sall were used to generate a second set of BACFAs and hybridized to DIG-labelled cDNA probes. Here, a band of $1.49 \mathrm{~kb}$ was predicted and then seen to be expressed at a higher level in $\mathrm{H} 37 \mathrm{Ra}$ versus $\mathrm{H} 37 \mathrm{Rv}$ (Fig. 2b). This fragment was found to contain the genes $f r d B$, frdC and frdD. After BACFA hybridization had been performed with cDNA probes derived from three independent populations of RNA extracted from intracellular H37Ra and H37Rv, 20 genes were selected for subsequent qPCR confirmation (Table 1).

\section{qPCR analysis of candidates selected after preliminary BACFA analysis}

Three independent pools of RNA from intracellular $M$. tuberculosis at $168 \mathrm{~h}$ post-infection were reverse transcribed as described for BACFA analysis and assessed via qPCR (Table 2). Expression trends as seen in BACFA were confirmed for $f r d B, f r d C, f r d D, p k s 2$, aceE and $R v 1571$ (Fig. 3a). $f r d B, f r d C$ and $f r d D$ all encode subunits of the fumarate reductase enzyme (FRD) complex, and are found in the frd operon (Cole et al., 1998). Another component of the operon is $f r d A$, whose gene product, FRD-A, along with FRD-B, constitutes the catalytic domain of the FRD complex. Even though $f r d A$ was not identified via BACFA, it was therefore included in the qPCR analysis. frdA was also found to show a higher expression level in H37Ra versus H37Rv (Fig. 3a) at $168 \mathrm{~h}$ post-infection.

FRD catalyses the conversion of fumarate into succinate, and has been demonstrated in vitro to also catalyse the

Table 1. Candidate genes identified via BACFA as being differentially expressed in intracellular $M$. tuberculosis H37Ra and H37Rv at $168 \mathrm{~h}$ post-infection

After hybridization of three populations of RNA, each done in duplicate, 20 genes were identified as being differentially expressed between the virulent and attenuated strains of M. tuberculosis. Information regarding gene function was obtained from the Tuberculist Web Server database (http://genolist.pasteur.fr/TubercuList/).

\begin{tabular}{|c|c|c|}
\hline Expression & Gene & Function \\
\hline \multirow[t]{6}{*}{$\mathrm{H} 37 \mathrm{Ra}>\mathrm{H} 37 \mathrm{Rv}$} & bioB $(R v 1589)$ & Biotin synthetase \\
\hline & $\operatorname{frdB}(R v 1553)$ & Fumarate reductase (iron-sulphur subunit) \\
\hline & $\operatorname{frdC}(R v 1554)$ & Fumarate reductase (membrane anchor subunit) \\
\hline & $\operatorname{frdD}(R v 1555)$ & Fumarate reductase (membrane anchor subunit) \\
\hline & rpoA $(R v 3457 c)$ & DNA-directed RNA polymerase (alpha chain) \\
\hline & $R v 1556$ & Possible regulatory protein \\
\hline \multirow[t]{14}{*}{$\mathrm{H} 37 \mathrm{Rv}>\mathrm{H} 37 \mathrm{Ra}$} & $\operatorname{ace} E(R v 2241)$ & E1 subunit of pyruvate dehydrogenase \\
\hline & $\operatorname{bioD}(R v 1570)$ & Dethiobiotin synthetase \\
\hline & $i c d 2(R v 0066 c)$ & Isocitrate dehydrogenase \\
\hline & $\operatorname{lpqL}(R v 0418)$ & Lipoprotein aminopeptidase \\
\hline & $\operatorname{lprN}(R v 3495 c)$ & Probable Mce-family lipoprotein \\
\hline & $\operatorname{narX}(R v 1736 c)$ & Nitrate reductase \\
\hline & pks2 (Rv3825c) & Polyketide synthase \\
\hline & $s d a A(R v 0069 c)$ & L-Serine dehydratase \\
\hline & $\operatorname{thiG}(\mathrm{Rv} 0417 c)$ & Thiamine biosynthesis protein \\
\hline & $\operatorname{trp} G(R v 0013)$ & Glutamine aminotransferase \\
\hline & $R v 0068 c$ & Probable oxidoreductase \\
\hline & $R v 0421 c$ & Conserved hypothetical protein \\
\hline & $R v 1571$ & Conserved hypothetical protein \\
\hline & $R v 1739 c$ & $\begin{array}{l}\text { Probable sulphur transport transmembrane } \\
\text { protein }\end{array}$ \\
\hline
\end{tabular}


Table 2. Primers used in $\mathrm{qPCR}$ confirmation of candidate genes

Sequences of primers used in qPCR confirmation of genes selected after three rounds of BACFA analysis of transcripts from M. tuberculosis H37Ra and H37Rv at 168 h post-infection. Primer sequences are presented $5^{\prime} \rightarrow 3^{\prime}$.

\begin{tabular}{|lll|}
\hline Gene & \multicolumn{1}{c|}{ Forward primer } & \multicolumn{1}{c|}{ Reverse primer } \\
\hline$a c e E(R v 2241)$ & TCC TGG CCA AGA CCA TCA AA & TGC GTG TCA CGA AAC TCC TT \\
$b i o B(R v 1589)$ & TCG CAA CGA AGT CGA GAT CA & CGT TTC GAG GTT GTG GTT GT \\
$b i o D(R v 1570)$ & TCA GAT CGT GCG GCT GAT & AAC TTG GTG TGG TTG AGG GT \\
$f r d A(R v 1552)$ & ATG GGC TAT GAC GAG TGG TT & GTC TTG ATG TTC GCG TTG GT \\
$f r d B(R v 1553)$ & AGG ATC ACC TCG ACG GAA CA & ACA ACG AGA TCG CGG ATC AC \\
$f r d C(R v 1554)$ & TGC TGC TGC ATG CTG TTA CC & ACC ATC CAG GCA ACG ATC AC \\
$f r d D(R v 1555)$ & TGC TGT TGC TGT TCG GAC TC & ACC AGG ACC AGC ACA ACA AG \\
$i c d 2(R v 0066 c)$ & CCA AGC ACC AGG AGC TGT TC & GTT CGT GGC AAC GGT GTA GG \\
$l p q L(R v 0418)$ & TGG CTG TGG TCG TCG CAT TC & GTT GGC GTT GGC GAT GTC CT \\
$l p r N(R v 3495 c)$ & ACC AAG GTG GAT TTC GGT GA & ACC GAA GTT GGG AAA TGG GA \\
$n a r X(R v 1736 c)$ & TGA CAT GAT GGG CGA ACT CT & CCG AAA TGA AAC ATC GGG CT \\
$p k s 2(R v 3825 c)$ & ACG GCT CCT ACA TCA TCA CC & GCA TTC CAC CAC GAC TTC AG \\
$r p o A(R v 3457 c)$ & CGG TCC TAC AAC TGC CTC AA & TCA CCT CGT CGA TGG ACT TC \\
$s d a A(R v 0069 c)$ & CGA GCG AAG GTG TGG TAT GA & GTG GAT TGC GTA TGA TCG AC \\
$t h i G(R v 0417 c)$ & GCC TGA TGC GGT CGA ATT AG & CTG CGC AAC CGG TAT CTT CT \\
$t r p G(R v 0013)$ & GGC CAC TCG ATA CCA TTC GT & ATC GAC TCC GGA TGG AAC TG \\
$R v 0068 c$ & CGG CCT GTT GAT TGA TCG AC & AAC AGC AGG TTG GCG AGC TT \\
$R v 0421 c$ & GTC GAA GCG ATC CAG CTG TG & GGA TGG ACC GGA TAG GAG AA \\
$R v 1556$ & AGT TCG TCG ACC ACC GTA AG & TGG ACC GGA AGA TGA GGT AG \\
$R v 1571$ & CGG GCC AAT GTC GTG TTC & AAT TGG TGA CCA CCG ACC C \\
$R v 1739 c$ & GTG GTG CAG TTC CGC GAA TA & ACG ATC CGA GCA GTG CGT AA \\
& \\
\hline
\end{tabular}

reverse reaction of reducing succinate to fumarate (Goldberg et al., 1983), normally done by the succinate dehydrogenase (SDH) enzyme complex. Previous studies of $s d h$ mutants in Escherichia coli have suggested that FRD can partially compensate for a lack of SDH activity (Guest, 1981). However, qPCR assessment of $s d h$ in H37Ra and $\mathrm{H} 37 \mathrm{Rv}$ indicated that not only is SDH present in both strains, but expression of these genes in the $s d h$ operon ( $s d h A, s d h B, s d h C$ and $s d h D$ ) did not differ between H37Ra and $\mathrm{H} 37 \mathrm{Rv}$ at $168 \mathrm{~h}$ post-infection (Fig. 3b).

\section{Assessment of candidate gene expression profiles in broth cultures and at $4 \mathrm{~h}$ and $96 \mathrm{~h}$ post-infection}

The $168 \mathrm{~h}$ post-infection time point was chosen primarily because that was the time at which sufficient RNA could be harvested for BACFA analysis. However, there remained the possibility that the significant difference we saw between H37Ra and H37Rv at $168 \mathrm{~h}$ post-infection was independent of events at earlier time points. Taking candidate genes identified as having expression differences at $168 \mathrm{~h}$ post-infection, the expression profiles of these genes were also assessed at 4 and $96 \mathrm{~h}$ post-infection (Fig. 4a). Expression profiles of the genes were also assessed for $\mathrm{PB}+\mathrm{T}$ broth cultures to determine whether the inter-strain differences are inherent or are more pronounced in interactions with the host macrophage (Fig. 4b, c).
Trends revealed via qPCR analysis indicate that genes of the frd operon are indeed expressed at higher levels in H37Ra at $168 \mathrm{~h}$ post-infection and in broth (Fig. 4a). However, at 4 and $96 \mathrm{~h}$ post-infection these genes are expressed at a higher level in the virulent H37Rv (Fig. 4a). This was reflected in a rapid expression of the frd operon following exposure of $\mathrm{H} 37 \mathrm{Rv}$ to the intracellular environment which then gradually declined over the course of the experiment (Fig. $4 \mathrm{a}, \mathrm{c})$. qPCR analysis also confirmed the upregulation of pks2, Rv1571 and aceE in intracellular H37Rv compared to $\mathrm{H} 37 \mathrm{Ra}$ at $168 \mathrm{~h}$ of interaction (Fig. 4a).

Expression of all frd operon genes was elevated in bacteria interacting with macrophages versus bacteria grown in enriched broth. This was manifested as a substantial increase in expression at $4 \mathrm{~h}$ that declined over the $168 \mathrm{~h}$ period of the experiment for both H37Rv and H37Ra (Fig. $4 b, c)$.

The upregulation of $p k s 2$ in macrophage-associated $M$. tuberculosis over that of broth-grown bacteria was maintained in $\mathrm{H} 37 \mathrm{Rv}$ from initial interaction throughout the infection (Fig. 4c). This trend was not detected in macrophage-associated $\mathrm{H} 37 \mathrm{Ra}$ at $4 \mathrm{~h}$ post-infection, but the expression of $p k s 2$ was observed to increase over the duration of the infection (Fig. 4b).

aceE displayed higher levels of expression in macrophageassociated bacteria versus broth-grown bacteria only at $168 \mathrm{~h}$ post-infection for both H37Ra and H37Rv (Fig. 4b, 
(a)

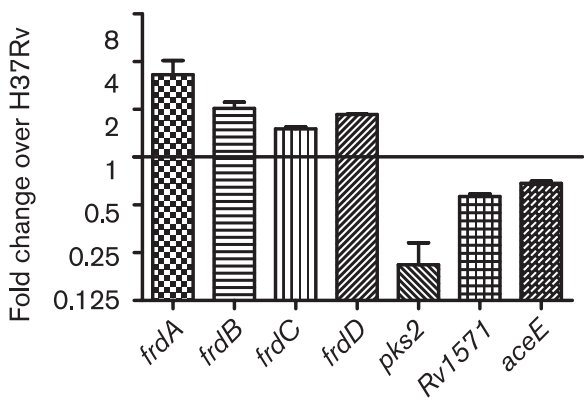

(b)

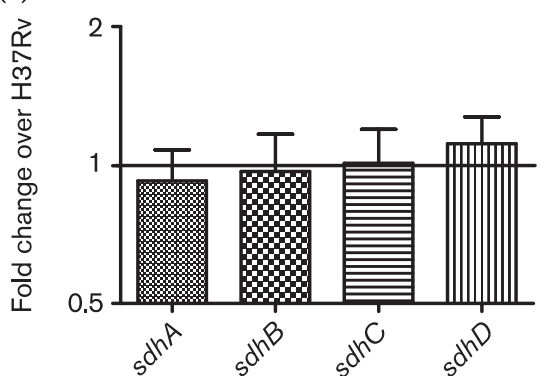

Fig. 3. $q P C R$ assessment of the expression profiles of selected candidate genes at $168 \mathrm{~h}$ post-infection. (a) Fold change of $\mathrm{frd} A$, frdB, frdC, frdD, pks2, Rv1571 and ace $E$ in intracellular H37Ra expressed as fold change over expression of these genes in intracellular H37Rv. (b) Expression of components of the sdh operon in intracellular H37Ra expressed as fold change over expression of these genes in intracellular H37Rv. The line drawn at ' 1 ' denotes expression in M. tuberculosis H37Rv. Data are means \pm SEM of three independent experiments.

c); however, levels of aceE transcript were higher in intracellular $\mathrm{H} 37 \mathrm{Rv}$ versus intracellular $\mathrm{H} 37 \mathrm{Ra}$ at all time points assessed during the infection (Fig. 4a).

Expression of $R v 1571$ was upregulated in intracellular H37Rv over H37Ra at both 4 and $168 \mathrm{~h}$ post-infection, but in broth, expression was 16-fold higher in H37Ra (Fig. 4a). Interestingly, the expression of $R v 1571$ was greatly enhanced in both H37Rv and H37Ra on exposure to the intracellular environment (Fig. 4b, c).

Lastly, statistical evaluation of gene expression revealed a significant difference between H37Ra and H37Rv for $\mathrm{frdC}$ at $96 \mathrm{~h}$ post-infection $(P=0.0068)$. However, statistical significance was not noted for the other genes.

\section{Growth of M. tuberculosis under oxygen-limiting conditions}

As FRD is an important enzyme in fumarate respiration, an energy-production pathway relied upon by bacteria exposed to anoxic environments, we assessed the growth of $\mathrm{H} 37 \mathrm{Ra}$ and $\mathrm{H} 37 \mathrm{Rv}$ under oxygen-limiting conditions similar to those described by Wayne (1976). Doubling times of H37Ra and H37Rv grown under these conditions (a)

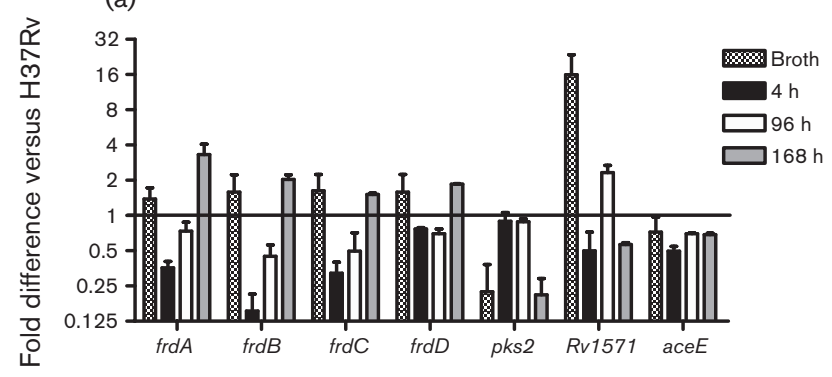

(b)

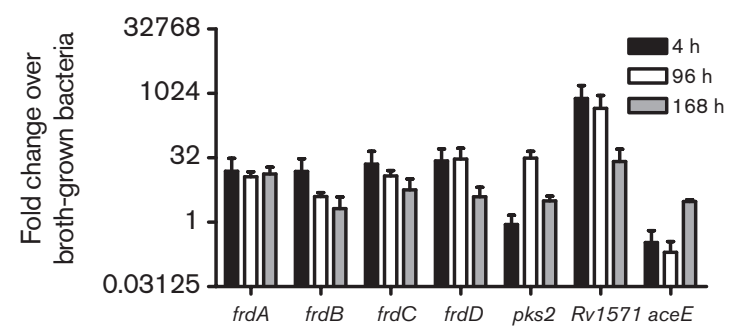

(c)

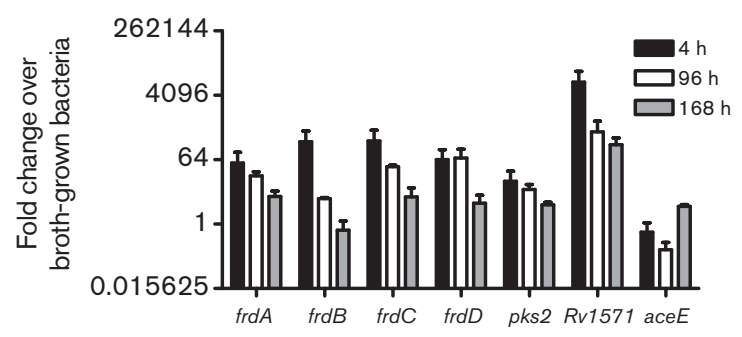

Fig. 4. $q P C R$ analysis of $f r d A, f r d B$, frdC, frdD, pks2, $R v 1571$ and ace $E$ identified via BACFA. (a) Expression of the respective genes in H37Ra and H37Rv in broth and at days 0, 4 and 7 within BM$M \Phi$, expressed as fold change of H37Ra expression over that of H37Rv. (b) Fold change of the genes in intracellular H37Ra over expression of the respective genes in H37Ra grown in $\mathrm{PB}+\mathrm{T}$ broth. (c) Fold change of the respective genes in intracellular H37Rv over expression of the genes in H37Rv grown in $\mathrm{PB}+\mathrm{T}$ broth. For (a), the line drawn at ' 1 ' denotes expression in intracellular M. tuberculosis H37Rv. For (b) and (c), the line drawn at ' 1 ' denotes expression in the respective strains grown in broth. Data are means \pm SEM of three independent experiments.

$(40.7 \pm 1.3 \mathrm{~h}$ for $\mathrm{H} 37 \mathrm{Ra} ; 45.9 \pm 7.9 \mathrm{~h}$ for H37Rv) differed significantly from either strain grown in aerated roller bottle cultures $(23.49 \pm 2.4 \mathrm{~h}$ for $\mathrm{H} 37 \mathrm{Ra} \quad P=0.0033$; $20.3 \pm 1.1 \mathrm{~h}$ for $\mathrm{H} 37 \mathrm{Rv}, P=0.0325)$. However, the growth rates of the oxygen-limited cultures of H37Ra and H37Rv were not significantly different $(P=0.297)$. All doubling times were calculated at day $5(120 \mathrm{~h})$.

\section{qPCR analysis of frd transcripts in oxygen-limited cultures of $M$. tuberculosis}

Concurrent with growth rate assessments of oxygenlimited cultures, RNA from these and their aerated culture 
counterparts were also harvested and levels of the frd transcripts were assessed. Transcripts from static cultures used to inoculate the low-oxygen and aerophilic cultures henceforth referred to as seed cultures - were also assessed to determine if changes after inoculation were pre-existing and strain specific. As seen in the previous experiment (Fig. 4a), seed cultures of M. tuberculosis H37Ra displayed higher levels of the frd transcripts compared to seed cultures of H37Rv (Fig. 5a). Comparable to the results with intracellular bacteria, $f r d A$ and $f r d B$ were expressed at a higher level in $\mathrm{H} 37 \mathrm{Rv}$ shortly after the oxygen constraints were initiated but, thereafter, H37Ra expression of these genes increased to levels higher than in H37Rv (Fig. 5a). Unlike the results obtained for intracellular bacteria, transcription of $f r d C$ and $f r d D$ was higher in H37Ra over the period of this study (Fig. 5a). Comparing the $\mathrm{frd}$ transcripts in oxygen-limited cultures versus their respective aerated culture counterparts, frd genes were expressed rapidly in oxygen-limited cultures of the virulent H37Rv, with a subsequent fall-off in expression levels over time (Fig. 5c). Expression of $f r d C$ in H37Ra followed a similar pattern but, in contrast, expression of $\operatorname{frd} A, B$ and $D$ was initially low, gradually increasing over the $96 \mathrm{~h}$ of the experiment. Using Student's $t$-test, only the expression of frdA and $f r d B$ at $4 \mathrm{~h}$ was significantly different between strains $(P=0.036,0.013$, respectively) whereas all other transcripts were not significantly different between strains.

\section{Effect of MNPO on the growth of extracellular and intracellular M. tuberculosis}

Mercaptopyridine- $N$-oxide (MPNO) has been previously described to negatively affect the growth of protozoan parasites (Turrens et al., 1999). In our hands, an inhibitory effect of MPNO on the growth of M. tuberculosis H37Ra and $\mathrm{H} 37 \mathrm{Rv}$ in $7 \mathrm{H} 9$ broth as measured by the reduction of AlamarBlue was observed over all concentrations tested (Fig. 6a). Interestingly, at the lowest concentration tested $(0.6 \mu \mathrm{M})$ inhibition of H37Ra was greater than that seen for H37Rv $(P=0.009)$.

To assess the importance of FRD for intracellular growth of mycobacteria, macrophages were infected and then cultured with medium supplemented with $2.4 \mu \mathrm{M}$ MPNO (Fig. 6b). This concentration was used as it was effective against both strains in broth and had previously been shown to be effective against intracellular protozoa while not affecting viability of host cells (Turrens et al., 1999). The growth of H37Ra and $\mathrm{H} 37 \mathrm{Rv}$ in untreated infected macrophages was similar to that obtained previously (Fig. 1c), with doubling times significantly different between the two strains at both $96 \mathrm{~h}(\mathrm{H} 37 \mathrm{Ra}, 51.5 \pm 1.7$; H37Rv, 32.8 $\pm 0.9 ; P=0.0007)$ and $168 \mathrm{~h}$ post-infection (H37Ra, 42.1 $\pm 1.6, H 37 \mathrm{Rv}, 31.3 \pm 0.8 ; P=0.0041$ ). There was a significant reduction of H37Ra and H37Rv c.f.u. in macrophages treated with MPNO with respect to their untreated counterparts at 96 and $168 \mathrm{~h}$ post-infection $(P<0.0001$ for all populations compared: Fig. 6). (a)

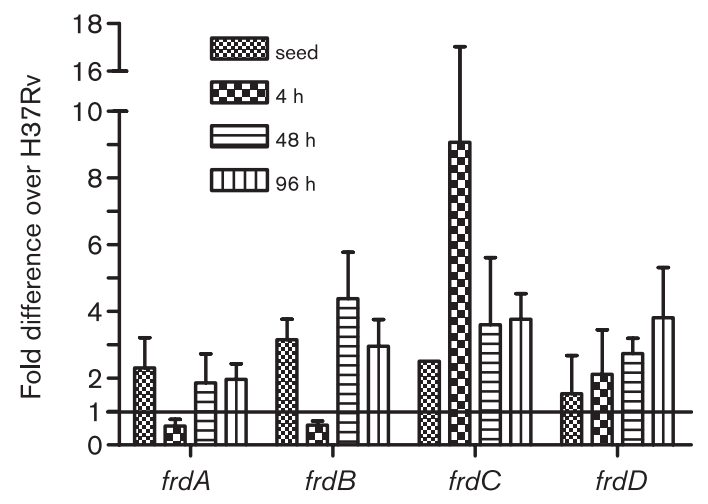

(b)

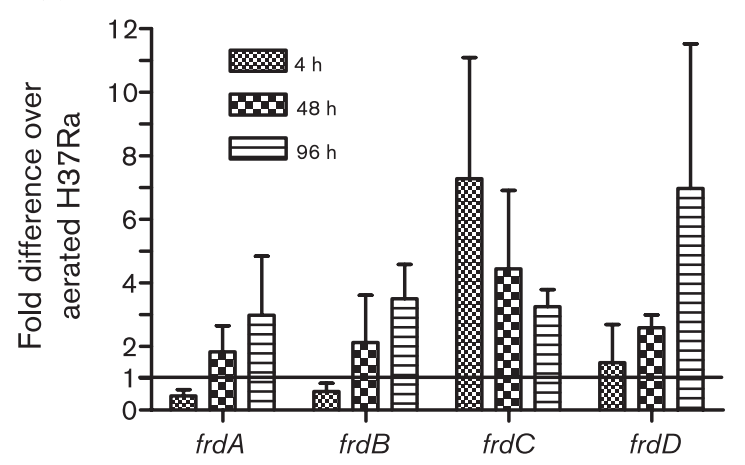

(c)

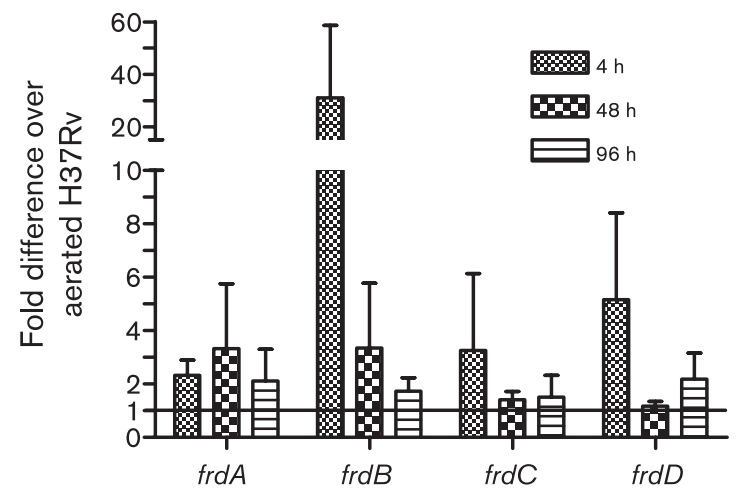

Fig. 5. $q P C R$ analysis of genes encoding fumarate reductase $(f r d A, f r d B$, frd $C$ and $f r d D$ ) in oxygen-limited and aerated broth cultures of M. tuberculosis H37Ra and H37Rv. (a) Expression of frd genes in oxygen-limited cultures of H37Ra and H37Rv, expressed as fold change of H37Ra over that of H37Rv. The line drawn at ' 1 ' denotes expression in M. tuberculosis H37Rv. (b) Fold change of frd genes in H37Ra grown under oxygen-limited conditions over that of the respective genes in H37Ra grown in aerated broth cultures. (c) Fold change of frd genes in H37Rv grown under oxygen-limited conditions over expression of the frd genes in aerated broth cultures of H37Rv. The lines drawn at ' 1 ' in (b) and (c) denote expression in aerated broth cultures of the respective strains. Data are means \pm SEM of three independent experiments. 
(a)

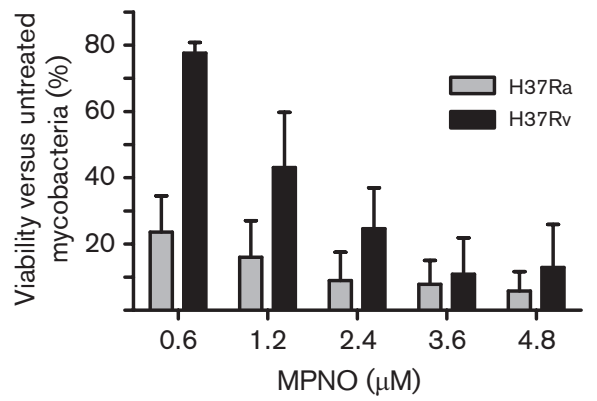

(b)

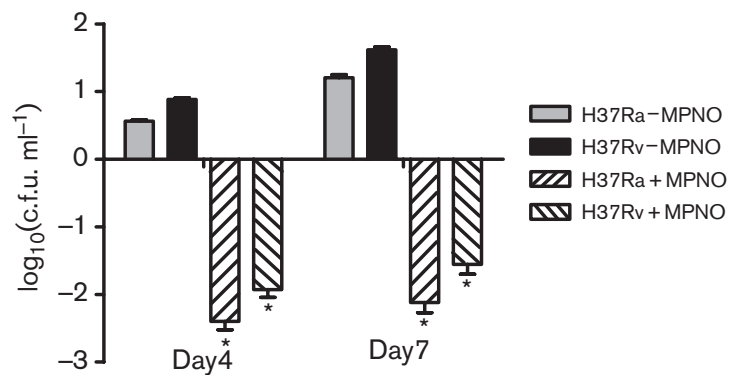

Fig. 6. Effect of MPNO on the growth of extracellular and intracellular M. tuberculosis. (a) M. tuberculosis H37Ra and H37Rv were grown in $7 \mathrm{H} 9$ and treated with a range of concentrations of MPNO for $72 \mathrm{~h}$. Viability of bacteria was assessed via the reduction of Alamar Blue reagent and expressed as a percentage of the viability seen in untreated mycobacteria. (b) Macrophage (BM-MФ) monolayers were treated with $2.4 \mu \mathrm{M}$ MPNO after being infected with M. tuberculosis H37Ra or H37Rv. C.f.u. of intracellular bacteria were enumerated at $96 \mathrm{~h}$ (day 4) and $168 \mathrm{~h}$ (day 7) and normalized to c.f.u. of bound or internalized bacteria at $4 \mathrm{~h}$ post-infection to assess changes in c.f.u. numbers as a result of macrophages receiving MPNO treatment. Data are means \pm SEM of three independent experiments. *, Significantly different from untreated counterpart $(P<0.0001)$.

Calculating death rates as previously described (Jannasch, 1969; Rahn, 1930) revealed a higher rate of killing of intracellular H37Ra compared to H37Rv in MPNO-treated macrophages at both $96 \mathrm{~h}$ (H37Ra death rate, $0.025 \pm 0.001$; $\mathrm{H} 37 \mathrm{Rv}$ death rate, $0.02 \pm 0.001)$ and $168 \mathrm{~h}$ (H37Ra death rate, $0.013 \pm 0.001 ; \mathrm{H} 37 \mathrm{Rv}$ death rate, $0.009 \pm 0.001)$. However, this did not reach significance levels $(96 \mathrm{~h}$, $P=0.051 ; 168$ h, $P=0.054)$.

\section{DISCUSSION}

In this present study, an alternative method of assessing expression differences in mycobacteria, bacterial artificial chromosome fingerprint array - BACFA - analysis, has been examined. As demonstrated here, this technique was able to identify both previously reported and novel, undescribed differences in expression, which were subse- quently confirmed by qPCR. BACFA, due to its nature, and cost-effectiveness, could be termed the 'poor-man's microarray'. Like the microarray, it utilizes labelled probes to detect target genes immobilized on a solid substrate; however, unlike microarray technology, BACFA can be performed by any laboratory that has access to standard equipment for gel electrophoresis and Southern blots. It does not require highly specialized equipment, nor does it require expensive reagents or even the large amounts of RNA that would be required for microarray assessments. Furthermore, unlike microarrays, BACFAs can be reused, as the DIG-dUTP-labelled-probes can be stripped and reused or the array may be rehybridized with a new probe. Additionally, microarray technology commonly utilizes ORFs present only in the reference strains selected by the manufacturers, which may overlook novel genomic sequences present in other strains or intergenic sequences that may be informative, whereas BACFA can allow for the analysis of these novel genomic sequences, provided that BACs spanning the region of interest are available. Overall, BACFA can be a viable, complementary alternative to microarray technology, but not a substitute, for there are considerations that may limit its use.

Firstly, the primer selected for the generation of DIGlabelled probes was of a defined sequence, which has the potential to limit the differences detected. However, in our experience random primers that would enable the screening of a more complex pool of transcripts did not allow for the generation of probes that could be used in expression analysis. Thus a compromise would be to use a defined primer of similar length, but different sequence, allowing for a different snapshot of the transcriptome. A further possibility would be to use genome-directed primers (Talaat et al., 2000) in separate RT and PCR applications, with pools of these probes enabling a more complex analysis of the differences between strains. For the present study, the arbitrary primers were used to elucidate the ability to generate meaningful BACFAs for $M$. tuberculosis; subsequent studies will make use of genomedirected primers.

A second consideration that affects the use of BACFAs in expression analyses is that one signal may be the result of several genes. It is this complication that will require resolution by generating alternative BACFAs with different sets of enzymes, which may be time-consuming. Conversely, this limitation is also an advantage of the BACFA method as it will allow for the identification of genes present on the same fragment that may be coregulated. As in the case of the frd operon isolated in this study, each gene on its own may not have given a signal intense enough to warrant further analysis. However, as three genes of the upregulated operon were present in one fragment, their combined signals led to the isolation of this operon. Ultimately, BACFA analyses can be a viable alternative to, if not a substitute for, other expression analysis techniques, particularly if cost and specialized facilities are of concern. 
Using the BACFA technique, both previously reported and novel differences were found. Differences in expression of pks2 (a gene whose product is thought to be involved in sulpholipid synthesis as well as other lipid synthesis roles: Sirakova et al., 2001) have been previously reported in transcriptome comparisons of broth-grown versus macrophage-associated H37Rv (Graham \& Clark-Curtiss, 1999). Similarly, we found that $p k s 2$ expression was upregulated in intracellular $\mathrm{H} 37 \mathrm{Rv}$ and H37Ra versus their broth-grown counterparts. Additionally, we report, apparently for the first time, that $p k s 2$ expression is higher in intracellular H37Rv versus H37Ra.

Previously unreported differences in gene expression identified using BACFA and subsequently confirmed via qPCR analyses were those of the genes Rv1571, aceE and frdD. aceE, seen to be expressed more readily in the virulent M. tuberculosis $\mathrm{H} 37 \mathrm{Rv}$ throughout the course of infection, encodes pyruvate decarboxylase, otherwise known as the E1 subunit for the pyruvate dehydrogenase complex (PDC). The PDC catalyses the conversion of pyruvate to acetyl-CoA, which feeds into the tricarboxylic acid cycle, one of the main pathways of cellular respiration and biosynthesis in both eukaryotes and prokaryotes (Madigan et al., 1997a). However, this E1 subunit can act independently of the PDC in glycolysis, converting pyruvate into acetaldehyde and a molecule of $\mathrm{CO}_{2}$ (Madigan et al., 1997a). Previous studies have shown that H37Rv displays a higher respiration rate than H37Ra (Heplar et al., 1954) and that H37Ra and H37Rv rely on both glycolytic and oxidative means of glucose metabolism, although H37Rv was seen to rely more heavily on glycolytic pathways (Ramakrishnan et al., 1962). aceE upregulation could help to support both aerobic and glycolytic pathways, acting either in concert with the rest of the PDC in aerobic respiration or independently as pyruvate decarboxylase under low-oxygen growth.

The dramatic increase in $R v 1571$ expression on transfer of both $\mathrm{H} 37 \mathrm{Rv}$ and H37Ra from broth to the intracellular environment is of interest and warrants further investigation. However, there was no consistent pattern of expression differences for this gene between intracellular H37Rv and H37Ra.

An additional difference found with BACFA analysis and confirmed with subsequent qPCR analysis was that of the components of the fumarate reductase (FRD) complex ( frdA, B, C and D). This enzyme complex catalyses the conversion of fumarate into succinate, and is composed of four subunits: FRD-A and FRD-B, which constitute the catalytic domain, and FRD-C and FRD-D, which constitute the anchoring domain. Fumarate respiration is an alternative means to acquire energy by utilizing fumarate as the terminal electron acceptor when oxygen or $\mathrm{NO}_{3}^{-}$is absent. BACFA analysis of $168 \mathrm{~h}$ post-infection transcripts revealed an upregulation of $f r d B, f r d C$ and $f r d D$ in H37Ra versus H37Rv. It was previously found in E. coli that FRD can partially compensate for missing succinate dehydrogenase (SDH) activity (Guest, 1981), a critical enzyme of the tricarboxylic acid cycle; however, PCR analysis of the $s d h$ operon in both H37Ra and H37Rv showed no genomic or expression differences between strains (Fig. 3b).

In mycobacterial studies, frdA has been found to be upregulated in $M$. tuberculosis interacting with the macrophage versus $M$. tuberculosis grown in broth cultures (Schnappinger et al., 2003) as well as in studies that examined the behaviour of $M$. tuberculosis grown under carbon starvation (Betts et al., 2002). Microarray studies examining the transcriptome in stationary-phase $M$. tuberculosis $\mathrm{H} 37 \mathrm{Rv}$ cultures found an increase of $f r d B$ and $f r d C$ transcripts versus bacteria in exponential growth (Raman et al., 2001). Additionally, investigations into the respiratory behaviour of Mycobacterium phlei found that FRD activity increased fourfold when bacteria were grown under low-oxygen conditions (Gillespie et al., 1988). Our studies have taken these initial observations further by including a direct comparison between $\mathrm{H} 37 \mathrm{Rv}$ and H37Ra in the intracellular environment as well as in broth culture. The recently published genomic sequence of $M$. tuberculosis H37Ra allowed the direct comparison of $f r d$ gene sequences of the two strains (Wang et al., 2007). However, no differences were noted in either the gene or promoter sequences of the $f r d$ operon in H37Ra and H37Rv (Cole et al., 1998; Wang et al., 2007). When we examined the expression of the frd operon over the duration of the infection period at 4,96 and $168 \mathrm{~h}$ post-infection, the trend observed was one where expression was initiated and climaxed earlier in the virulent $\mathrm{H} 37 \mathrm{Rv}$ strain versus that in the attenuated H37Ra. These results support a hypothesis where $\mathrm{H} 37 \mathrm{Rv}$ is able to respond more quickly to the challenge of the intracellular environment - possibly in response to the oxygen-limited conditions encountered inside the macrophage (Schnappinger et al., 2003), thereby resulting in enhanced replication within the macrophage.

To address the role of FRD under anoxic conditions, we sought to characterize FRD activity and frd transcripts in cultures of M. tuberculosis $\mathrm{H} 37 \mathrm{Rv}$ and H37Ra grown as both unaerated static (oxygen-limited) and aerated rollerbottle cultures. The attenuated strain grown under lowoxygen conditions displayed a lag in gene expression with regard to the catalytic domain of FRD ( $f r d A, f r d B)$ but not the anchoring domain $(f r d C$, $f r d D)$. The data do not exactly reproduce the trends seen with the intracellular bacteria, probably due to the multiple challenges encountered by the bacterium inside host cells. As such, although H37Ra is observed to transcribe the genes encoding the anchoring domain at even a higher level than H37Rv, the lag in transcription of the catalytic subdomain could limit the function of the complex as a whole.

None of the frd genes were found in the TraSH (transposon site hybridization) screens used to identify genes essential for survival of the bacterium in macrophages and in mice (Rengarajan et al., 2005; Sassetti \& Rubin, 2003). However, 
as the authors state when comparing their results to expression analysis, their findings 'emphasize the complementary nature of the two experimental approaches' and that $\mathrm{TraSH}$ may fail to pick up 'mutants that are complemented in trans by either bacterial or host factors' (Rengarajan et al., 2005). In addition, TraSH would not identify differences such as we found, where differences in the kinetics of frd gene expression correlated with differences between H37Ra and H37Rv in their intracellular growth and virulence. Thus, the absence of the frd genes in the $\mathrm{TraSH}$ screens does not minimize the importance of FRD in M. tuberculosis infections. Studies of directed knockout mutants of all frd genes in addition to knockout mutants of individual frd genes have been initiated and are ongoing.

The transcriptomic data from the infection study suggested a role for FRD in the intracellular survival of M. tuberculosis. We therefore investigated the effect of a putative FRD inhibitor, MPNO, on the growth of intracellular $M$. tuberculosis. The FRD enzyme complex is not found in mammalian cells (Ge, 2002; Phillips et al., 1987; Van Hellemond \& Tielens, 1994), so FRD inhibitors are expected to have low to negligible adverse effects upon the viability of mammalian cells (Ge, 2002). With regard to other pathogenic organisms, FRD has been considered a target in the treatment of Helicobacter pylori, as it was found to be an essential gene in the establishment of $H$. pylori colonization of the mouse stomach (Birkholz et al., 1994; Ge et al., 2000; Wang et al., 2000). Furthermore, FRD has been reported to be a successful target in the treatment of protozoan and helminth infections using a variety of compounds (Bryant \& Bennet, 1983; Chen et al., 2001; Omura et al., 2001; Prichard, 1973; Turrens et al., 1996, 1999), although it should be emphasized that the specificity of these compounds for FRD has not been established and the mode of action of at least some of the compounds is unclear.

MPNO is a common antimicrobial and antifungal ingredient in household products. It has been characterized to be an inhibitor of protozoa and is the precursor to L921-021, a drug developed and implemented for the treatment of protozoan infections. However, it should be stressed that although MPNO has been reported to inhibit FRD activity (Turrens et al., 1999), its mode of action is not understood and the specificity of MPNO for FRD has not been demonstrated.

For our purposes of examining MPNO effects on the intracellular growth of M. tuberculosis H37Ra and H37Rv, we used the concentration of the inhibitor previously used to inhibit the growth of the intracellular parasite Trypanasoma cruzi without adverse effects on mammalian cells (Turrens et al., 1999). The significant reduction in intracellular bacteria in MPNO-treated macrophages throughout the study was possibly due to inhibitory effects of the inhibitor on bacterial FRD. However, as the literature provides no real understanding of the mode of action of MPNO, it is not yet possible to determine whether the MPNO was acting on other bacterial systems to produce its mycobactericidal effect. Indeed, the specificity of MPNO and other reported FRD inhibitors has not been demonstrated (Bryant \& Bennet, 1983; Chen et al., 2001; Omura et al., 2001; Prichard, 1973; Turrens et al., 1996, 1999). Further work will be necessary before we can be sure that other putative FRD inhibitors have activity against extracellular and intracellular M. tuberculosis and that any observed activity is indeed due solely to inhibition of FRD. Nevertheless, our observations indicate that MPNO and other putative FRD inhibitors warrant further investigation as anti-mycobacterials.

In this study we have outlined an alternative means to study transcriptomes of intracellular bacteria. Using BACFA, we have identified differences between virulent and attenuated strains of $M$. tuberculosis that may ultimately help to explain why these highly related bacteria have such different phenotypes when interacting with the host. We have also characterized the expression profile of the genes encoding the FRD enzyme complex, which in other organisms provides energy and substrates under suboptimal conditions, and which appears to play a supportive role in the survival of $M$. tuberculosis in macrophages.

\section{ACKNOWLEDGEMENTS}

The M. tuberculosis H37Rv BAC library was a generous gift from Drs Stewart Cole and Roland Brosch. Dr Philip Butcher provided invaluable technical advice and protocols on RNA extraction and techniques. BAC fingerprint arrays were generated with protocols and advice supplied by Dr Roland Brosch and Chad Malloff. The programme Restriction Site Digest was scripted by Bryan Chi, and modified for use with M. tuberculosis by Steven Pleasance. We would also like to thank Sharlene Eivemark for technical support and Dr K. G. Papavinasasundaram for his insightful comments. This study was funded by the Canadian Bacterial Diseases Network, Networks of Centres of Excellence, the British Columbia Lung Association, and the British Columbia TB Vets Foundation. R.W.S. is the recipient of a Child and Family Research Institute Investigatorship Award. A. L. was supported by a Hardwick Fellowship from the Department of Pathology, University of British Columbia, and a graduate fellowship from the Child and Family Research Institute.

\section{REFERENCES}

Bacon, J., James, B. W., Wernisch, L., Williams, A., Morley, K. A., Hatch, G. J., Mangan, J. A., Hinds, J., Stoker, N. G. \& other authors (2004). The influence of reduced oxygen availability on pathogenicity and gene expression in Mycobacterium tuberculosis. Tuberculosis (Edinb) 84, 205-217.

Betts, J. C., Lukey, P. T., Robb, L. C., McAdam, R. A. \& Duncan, K. (2002). Evaluation of a nutrient starvation model of Mycobacterium tuberculosis persistence by gene and protein expression profiling. Mol Microbiol 43, 717-731.

Bhargava, S., Tyagi, A. K. \& Tyagi, J. S. (1990). tRNA genes in mycobacteria: organization and molecular cloning. J Bacteriol 172, 2930-2934.

Birkholz, S., Knipp, U., Lemma, E., Kroger, A. \& Opferkuch, W. (1994). Fumarate reductase of Helicobacter pylori - an immunogenic protein. J Med Microbiol 41, 56-62. 
Brosch, R., Gordon, S. V., Billault, A., Garnier, T., Eiglmeier, K., Soravito, C., Barrell, B. G. \& Cole, S. T. (1998). Use of a Mycobacterium tuberculosis $\mathrm{H} 37 \mathrm{Rv}$ bacterial artificial chromosome library for genome mapping, sequencing, and comparative genomics. Infect Immun 66, 2221-2229.

Brosch, R., Philipp, W. J., Stavropoulos, E., Colston, M. J., Cole, S. T. \& Gordon, S. V. (1999). Genomic analysis reveals variation between Mycobacterium tuberculosis $\mathrm{H} 37 \mathrm{Rv}$ and the attenuated M. tuberculosis H37Ra strain. Infect Immun 67, 5768-5774.

Bryant, C. \& Bennet, E. M. (1983). Observations on the fumarate reductase system in Haemonchus contortus and their relevance to anthelmintic resistance and to strain variations of energy metabolism. Mol Biochem Parasitol 7, 281-292.

Chen, M., Zhai, L., Christensen, S. B., Theander, T. G. \& Kharazmi, A. (2001). Inhibition of fumarate reductase in Leishmania major and $L$. donovani by chalcones. Antimicrob Agents Chemother 45, 2023-2029.

Cole, S. T., Brosch, R., Parkhill, J., Garnier, T., Churcher, C., Harris, D., Gordon, S. V., Eiglmeier, K., Gas, S. \& other authors (1998). Deciphering the biology of Mycobacterium tuberculosis from the complete genome sequence. Nature 393, 537-544.

Collins, D. M. \& De Lisle, G. W. (1984). DNA restriction endonuclease analysis of Mycobacterium tuberculosis and Mycobacterium bovis BCG. J Gen Microbiol 130, 1019-1021.

Collins, F. M. \& Smith, M. M. (1969). A comparative study of the virulence of Mycobacterium tuberculosis measured in mice and guinea pigs. Am Rev Respir Dis 100, 631-639.

Dasgupta, N., Kapur, V., Singh, K. K., Das, T. K., Sachdeva, S., Jyothisri, K. \& Tyagi, J. S. (2000). Characterization of a twocomponent system, devR-devS, of Mycobacterium tuberculosis. Tuber Lung Dis 80, 141-159.

Dolin, P. J., Raviglione, M. C. \& Kochi, A. (1994). Global tuberculosis incidence and mortality during 1990-2000. Bull World Health Organ 72, 213-220.

Gao, Q., Kripke, K., Arinc, Z., Voskuil, M. \& Small, P. (2004). Comparative expression studies of a complex phenotype: cord formation in Mycobacterium tuberculosis. Tuberculosis (Edinb) 84, $188-196$.

Ge, Z. (2002). Potential of fumarate reductase as a novel therapeutic target in Helicobacter pylori infection. Expert Opin Ther Targets 6, 135-146.

Ge, Z., Feng, Y., Dangler, C. A., Xu, S., Taylor, N. S. \& Fox, J. G. (2000). Fumarate reductase is essential for Helicobacter pylori colonization of the mouse stomach. Microb Pathog 29, 279-287.

Gillespie, J., Barton, L. L. \& Rypka, E. W. (1988). Influence of oxygen tension on the respiratory activity of Mycobacterium phlei. J Gen Microbiol 134, 247-252.

Goldberg, I., Lonberg-Holm, K., Bagley, E. A. \& Stieglitz, B. (1983). Improved conversion of fumarate to succinate by Escherichia coli strains amplified for fumarate reductase. Appl Environ Microbiol 45, 1838-1847.

Gordon, S. V., Brosch, R., Billault, A., Garnier, T., Eiglmeier, K. \& Cole, S. T. (1999a). Identification of variable regions in the genomes of tubercle bacilli using bacterial artificial chromosome arrays. Mol Microbiol 32, 643-655.

Gordon, S. V., Heym, B., Parkhill, J., Barrell, B. \& Cole, S. T. (1999b). New insertion sequences and a novel repeated sequence in the genome of Mycobacterium tuberculosis H37Rv. Microbiology 145, 881892.

Graham, J. E. \& Clark-Curtiss, J. E. (1999). Identification of Mycobacterium tuberculosis RNAs synthesized in response to phagocytosis by human macrophages by selective capture of transcribed sequences (SCOTS). Proc Natl Acad Sci U S A 96, 11554-11559.
Guest, J. R. (1981). Partial replacement of succinate dehydrogenase function by phage- and plasmid-specified fumarate reductase in Escherichia coli. J Gen Microbiol 122, 171-179.

Guinn, K. M., Hickey, M. J., Mathur, S. K., Zakel, K. L., Grotzke, J. E., Lewinsohn, D. M., Smith, S. \& Sherman, D. R. (2004). Individual RD1-region genes are required for export of ESAT-6/CFP-10 and for virulence of Mycobacterium tuberculosis. Mol Microbiol 51, 359-370.

Heplar, J. Q., Clifton, C. E., Raffel, S. \& Futrelle, C. M. (1954). Virulence of the tubercle bacillus. I. Effect of oxygen tension upon respiration of virulent and avirulent bacilli. J Infect Dis 94, 90-98.

Imaeda, T. (1985). Deoxyribonucleic acid relatedness among strains of Mycobacterium tuberculosis, Mycobacterium bovis BCG, Mycobacterium microti and Mycobacterium africanum. Int J Syst Bacteriol 35, 147-150.

Jannasch, H. W. (1969). Estimations of bacterial growth rates in natural waters. J Bacteriol 99, 156-160.

Jung, Y. J., LaCourse, R., Ryan, L. \& North, R. J. (2002). Virulent but not avirulent Mycobacterium tuberculosis can evade the growth inhibitory action of a T helper 1-dependent, nitric oxide synthase 2-independent defense in mice. J Exp Med 196, 991-998.

Kinger, A. K. \& Tyagi, J. S. (1993). Identification and cloning of genes differentially expressed in the virulent strain of Mycobacterium tuberculosis. Gene 131, 113-117.

Lari, N., Rindi, L. \& Garzelli, C. (2001). Identification of one insertion site of IS6110 in Mycobacterium tuberculosis H37Ra and analysis of the RvD2 deletion in M. tuberculosis clinical isolates. J Med Microbiol 50, 805-811.

Li, M. S., Monahan, I. M., Waddell, S. J., Mangan, J. A., Martin, S. L., Everett, M. J. \& Butcher, P. D. (2001). cDNA-RNA subtractive hybridization reveals increased expression of mycocerosic acid synthase in intracellular Mycobacterium bovis BCG. Microbiology 147, 2293-2305.

Madigan, M. T., Martinko, J. M. \& Parker, J. (1997a). Nutrition and metabolism. In Brock Biology of Microorganisms, 8th edn, pp. 111-150. Upper Saddle River, NJ: Prentice-Hall.

Madigan, M. T., Martinko, J. M. \& Parker, J. (1997b). Microbial growth. In Brock Biology of Microorganisms, 8th edn, pp. 151-179. Upper Saddle River, NJ: Prentice-Hall.

Mangan, J. A. \& Butcher, P. D. (1998). Analysis of mycobacterial differential gene expression by RAP-PCR. Methods Mol Biol 101, 307-322.

Mangan, J. A., Sole, K. M., Mitchison, D. A. \& Butcher, P. D. (1997). An effective method of RNA extraction from bacteria refractory to disruption, including mycobacteria. Nucleic Acids Res 25, 675-676.

Menendez Mdel, C., Rebollo, M. J., Nunez Mdel, C., Cox, R. A. \& Garcia, M. J. (2005). Analysis of the precursor rRNA fractions of rapidly growing mycobacteria: quantification by methods that include the use of a promoter (rrnA P1) as a novel standard. J Bacteriol 187, 534-543.

Monahan, I. M., Betts, J., Banerjee, D. K. \& Butcher, P. D. (2001). Differential expression of mycobacterial proteins following phagocytosis by macrophages. Microbiology 147, 459-471.

Monod, J. (1949). The growth of bacterial cultures. Annu Rev Microbiol 3, 371-394.

Mostowy, S., Cleto, C., Sherman, D. R. \& Behr, M. A. (2004). The Mycobacterium tuberculosis complex transcriptome of attenuation. Tuberculosis (Edinb) 84, 197-204.

Narain, J. P., Raviglione, M. C. \& Kochi, A. (1992). HIV-associated tuberculosis in developing countries: epidemiology and strategies for prevention. Tuber Lung Dis 73, 311-321.

Oatway, W. H. \& Steenken, W (1936). The pathogenesis and fate of tubercle produced by dissociate variants of tubercle bacilli. J Infect Dis 59, 306-325. 
Omura, S., Miyadera, H., Ui, H., Shiomi, K., Yamaguchi, Y., Masama, R., Nagamitsu, T., Takano, D., Sunazuka, T. \& other authors (2001). An anthelmintic compound, nafuredin, shows selective inhibition of complex I in helminth mitochondria. Proc Natl Acad Sci U S A 98, 60-62.

Park, H. D., Guinn, K. M., Harrell, M. I., Liao, R., Voskuil, M. I., Tompa, M., Schoolnik, G. K. \& Sherman, D. R. (2003). Rv3133c/dosR is a transcription factor that mediates the hypoxic response of Mycobacterium tuberculosis. Mol Microbiol 48, 833-843.

Phillips, M. K., Hederstedt, L., Hasnain, S., Rutberg, L. \& Guest, J. R. (1987). Nucleotide sequence encoding the flavoprotein and ironsulfur protein subunits of the Bacillus subtilis PY79 succinate dehydrogenase complex. J Bacteriol 169, 864-873.

Prichard, R. K. (1973). The fumarate reductase reaction of Haemonchus contortus and the mode of action of some anthelmintics. Int J Parasitol 3, 409-417.

Rahn, O. (1930). The non-logarithmic order of death of some bacteria. J Gen Physiol 13, 395-407.

Ramakrishnan, T., Indira, M. \& Maller, R. K. (1962). Evaluation of the routes of glucose utilization in virulent and avirulent strains of Mycobacterium tuberculosis. Biochim Biophys Acta 59, 529-532.

Raman, S., Song, T., Puyang, X., Bardarov, S., Jacobs, W. R., Jr \& Husson, R. N. (2001). The alternative sigma factor SigH regulates major components of oxidative and heat stress responses in Mycobacterium tuberculosis. J Bacteriol 183, 6119-6125.

Rengarajan, J., Bloom, B. R. \& Rubin, E. J. (2005). Genome-wide requirements for Mycobacterium tuberculosis adaptation and survival in macrophages. Proc Natl Acad Sci U S A 102, 8327-8332.

Rindi, L., Lari, N. \& Garzelli, C. (1999). Search for genes potentially involved in Mycobacterium tuberculosis virulence by mRNA differential display. Biochem Biophys Res Commun 258, 94-101.

Rindi, L., Lari, N. \& Garzelli, C. (2001). Genes of Mycobacterium tuberculosis $\mathrm{H} 37 \mathrm{Rv}$ downregulated in the attenuated strain H37Ra are restricted to M. tuberculosis complex species. New Microbiol 24, 289-294.

Rivera-Marrero, C. A., Burroughs, M. A., Masse, R. A., Vannberg, F. O., Leimbach, D. L., Roman, J. \& Murtagh, J. J., Jr (1998). Identification of genes differentially expressed in Mycobacterium tuberculosis by differential display PCR. Microb Pathog 25, 307-316.

Rooyakkers, A. W. \& Stokes, R. W. (2005). Absence of complement receptor 3 results in reduced binding and ingestion of Mycobacterium tuberculosis but has no significant effect on the induction of reactive oxygen and nitrogen intermediates or on the survival of the bacteria in resident and interferon-gamma activated macrophages. Microb Pathog 39, 57-67.

Saini, D. K., Malhotra, V., Dey, D., Pant, N., Das, T. K. \& Tyagi, J. S. (2004). DevR-DevS is a bona fide two-component system of Mycobacterium tuberculosis that is hypoxia-responsive in the absence of the DNA-binding domain of DevR. Microbiology 150, 865-875.

Sassetti, C. M. \& Rubin, E. J. (2003). Genetic requirements for mycobacterial survival during infection. Proc Natl Acad Sci U S A 100, 12989-12994.

Schmittgen, T. D., Zakrajsek, B. A., Mills, A. G., Gorn, V., Singer, M. J. \& Reed, M. W. (2000). Quantitative reverse transcription-polymerase chain reaction to study mRNA decay: comparison of endpoint and real-time methods. Anal Biochem 285, 194-204.

Schnappinger, D., Ehrt, S., Voskuil, M. I., Liu, Y., Mangan, J. A., Monahan, I. M., Dolganov, G., Efron, B., Butcher, P. D. \& other authors (2003). Transcriptional adaptation of Mycobacterium tuberculosis within macrophages: insights into the phagosomal environment. J Exp Med 198, 693-704.

Selwyn, P. A., Hartel, D., Lewis, V. A., Schoenbaum, E. E., Vermund, S. H., Klein, R. S., Walker, A. T. \& Friedland, G. H. (1989). A prospective study of the risk of tuberculosis among intravenous drug users with human immunodeficiency virus infection. $N$ Engl J Med 320, 545-550.

Sirakova, T. D., Thirumala, A. K., Dubey, V. S., Sprecher, H. \& Kolattukudy, P. E. (2001). The Mycobacterium tuberculosis pks2 gene encodes the synthase for the hepta- and octamethyl-branched fatty acids required for sulfolipid synthesis. J Biol Chem 276, 16833-16839.

Steenken, W. \& Gardner, L. U. (1946). History of H37 strain of tubercle bacillus. Am Rev Respir Dis 54, 62-66.

Steenken, W., Jr, Oatway, W. H. \& Petroff, S. A. (1934). Biological studies of the tubercle bacillus. III. Dissociation and pathogenicity of the R and $\mathrm{S}$ variants of the human tubercle bacillus (H37). J Exp Med 60, 515-540.

Stewart, G. R., Wernisch, L., Stabler, R., Mangan, J. A., Hinds, J., Laing, K. G., Young, D. B. \& Butcher, P. D. (2002). Dissection of the heat-shock response in Mycobacterium tuberculosis using mutants and microarrays. Microbiology 148, 3129-3138.

Stokes, R. W., Haidl, I. D., Jefferies, W. A. \& Speert, D. P. (1993). Mycobacteria-macrophage interactions. Macrophage phenotype determines the nonopsonic binding of Mycobacterium tuberculosis to murine macrophages. J Immunol 151, 7067-7076.

Talaat, A. M., Hunter, P. \& Johnston, S. A. (2000). Genome-directed primers for selective labeling of bacterial transcripts for DNA microarray analysis. Nat Biotechnol 18, 679-682.

Turrens, J. F., Watts, B. P., Jr, Zhong, L. \& Docampo, R. (1996). Inhibition of Trypanosoma cruzi and T. brucei NADH fumarate reductase by benznidazole and anthelmintic imidazole derivatives. Mol Biochem Parasitol 82, 125-129.

Turrens, J. F., Newton, C. L., Zhong, L., Hernandez, F. R., Whitfield, J. \& Docampo, R. (1999). Mercaptopyridine- $N$-oxide, an $\mathrm{NADH}-$ fumarate reductase inhibitor, blocks Trypanosoma cruzi growth in culture and in infected myoblasts. FEMS Microbiol Lett 175, 217-221.

Van Hellemond, J. J. \& Tielens, A. G. (1994). Expression and functional properties of fumarate reductase. Biochem J 304, 321-331.

Vandesompele, J., De Preter, K., Pattyn, F., Poppe, B., Van Roy, N., De Paepe, A. \& Speleman, F. (2002). Accurate normalization of realtime quantitative RT-PCR data by geometric averaging of multiple internal control genes. Genome Biol 3, RESEARCH0034.

Waddell, S. J., Chung, G. A., Gibson, K. J., Everett, M. J., Minnikin, D. E., Besra, G. S. \& Butcher, P. D. (2005). Inactivation of polyketide synthase and related genes results in the loss of complex lipids in Mycobacterium tuberculosis H37Rv. Lett Appl Microbiol 40, 201-206.

Wang, S., Liu, F. \& Zhao, B. (2000 ). Study on mRNA differential display in Mycobacterium tuberculosis H37Rv and H37Ra. Zhonghua Jie He He Hu Xi Za Zhi 23, 669-671.

Wang, S. Y., Zheng, H. J., Wang, B. F., Zhang, X. L., Pu, S. Y., Zhu, G. F. \& Zhao, G. P. (2007). Complete genomic sequence of Mycobacterium tuberculosis strain H37Ra, a non-pathogenic variant closely related to the well-characterized pathogenic strain H37Rv. GenBank Accession Number: CP000611, http://www.ncbi.nlm.nih. gov/entrez/viewer.fcgi?db=nuccore\&id=148503909

Wayne, L. G. (1976). Dynamics of submerged growth of Mycobacterium tuberculosis under aerobic and microaerophilic conditions. Am Rev Respir Dis 114, 807-811.

Wei, J., Dahl, J. L., Moulder, J. W., Roberts, E. A., O'Gaora, P., Young, D. B. \& Friedman, R. L. (2000). Identification of a Mycobacterium tuberculosis gene that enhances mycobacterial survival in macrophages. J Bacteriol 182, 377-384.

Wernisch, L., Kendall, S. L., Soneji, S., Wietzorrek, A., Parish, T., Hinds, J., Butcher, P. D. \& Stoker, N. G. (2003). Analysis of whole-genome microarray replicates using mixed models. Bioinformatics 19, 53-61.

Edited by: S. V. Gordon 